\title{
The Paradigm of Hakka Women in History
}

\author{
Sabrina ARDIZZONI*
}

\begin{abstract}
Hakka studies rely strongly on history and historiography. However, despite the fact that in rural Hakka communities women play a central role, in the main historical sources women are almost absent. They do not appear in genealogy books, if not for their being mothers or wives, although they do appear in some legends, as founders of villages or heroines who distinguished themselves in defending the villages in the absence of men. They appear in modern Hakka historiography-Hakka historiography is a very recent discipline, beginning at the end of the 19th century - for their moral value, not only for adhering to Confucian traditional values, but also for their endorsement of specifically Hakka cultural values. In this paper we will analyse the cultural paradigm that allows women to become part of Hakka history. We will show how ethical values are reflected in Hakka historiography through the reading of the earliest Hakka historians as they depicted Hakka women. Grounded on these sources, we will see how the narration of women in Hakka history has developed until the present day.

In doing so, it is necessary to deal with some relevant historical features in the construction of Hakka group awareness, namely migration, education, and women narratives, as a pivotal foundation of Hakka collective social and individual consciousness.
\end{abstract}

Keywords: Hakka studies, Hakka woman, women practices, West Fujian

\section{Paradigma žensk Hakka v zgodovini}

\section{Izvleček}

Študije skupnosti Hakka se močno opirajo na zgodovino in zgodovinopisje. Kljub temu da imajo ženske v podeželskih skupnostih Hakka osrednjo vlogo, v glavnih zgodovinskih virih skorajda niso omenjene. $V$ rodoslovnih knjigah se ne pojavljajo, razen kot matere ali žene, čeprav se v nekaterih legendah pojavljajo kot ustanoviteljice vasi ali junakinje, ki so se v odsotnosti moških odlikovale v obrambi vasi. Pojavljajo pa se v sodobnem zgodovinopisju skupnosti Hakka, tj. v najnovejši disciplini z začetki konec 19. stoletja, in sicer zaradi svoje moralne vrednosti, torej ne le zaradi spoštovanja konfucijanskih tradicionalnih vrednot, temveč tudi zaradi specifičnih kulturnih vrednot skupnosti Hakka. V tem prispevku bomo analizirali kulturno paradigmo, ki ženskam omogoča, da postanejo del zgodovine skupnosti Hakka. S pregledom najzgodnejših zgodovinarjev te skupnosti, ki so opisovali

Sabrina ARDIZZONI, PhD Adjunct Professor of Chinese Language and Culture, Chinese Language and Literature, University of Bologna, Italy. E-mail address: sabrina.ardizzoni@unibo.it

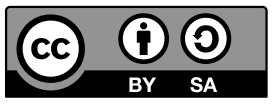


ženske Hakka, bomo pokazali, kako se etične vrednote odražajo v zgodovini te skupnosti. $\mathrm{Na}$ podlagi teh virov bomo videli, kako se je naracija o ženskah v zgodovini skupnosti Hakka razvijala do danes.

Pri tem se je treba spoprijeti z nekaterimi pomembnimi zgodovinskimi značilnostmi pri oblikovanju zavedanja o skupnosti Hakka, in sicer z migracijami, izobraževanjem in ženskimi pripovedmi, ki so ključni temelj kolektivne družbene in individualne zavesti skupnosti Hakka.

Ključne besede: študije skupnosti Hakka, ženske Hakka, ženske prakse, zahodni Fujian

\section{Introduction}

The role of Hakka women in Hakka history is a central but contradictory one. Whereas the history of Hakka lineages goes back to fairly ancient times, Hakka historiography is a relatively recent arrival, and coincides with the process of group-cohesion construction. This cohesion is based on establishing a distinction from nearby groups, without distancing one's self too much from the Han, and is based on historical and cultural features.

Hakka studies are strongly grounded in history, interlacing the family history of migrating Han groups - at first from the Central Plains to the southern regions of Zhejiang, Fujian, Guangdong, Jiangxi, and later towards Guangxi, Sichuan, and Hunan一with local history as recorded in local Gazetteers (difang zhi 地方 志) as well as in family and genealogy records (jiapu 家谱 and zupu 族谱). The aim of this paper is to analyse the narrative lines emerging from Hakka studies conducted from the end of the 19th century to the present. We will see how some relevant historical features in the construction of Hakka group-awareness, namely migration, education, and different narrative threads on Hakka woman (kejia nüxing 客家女性), are a crucial foundation for Hakka collective social and individual consciousness. To do so, we will consider Hakka historiography, looking for the socio-cultural features which bring the Hakka woman into Hakka history. Highlighting the multi-faceted historiographic narrative that reflects the cultural framework of womanhood in the Hakka social context, we seek to answer the following question: what is the paradigm of women in Hakka culture, as reflected in Hakka history and society? Our analysis of Hakka historiography shows that, in Hakka history, women have had and continue to have an axiomatic role as a social subject, because of their ethical/functional value. The multi-faceted representation of Hakka women in historiography and in oral and artistic popular tradition mirrors the integration of diverse strata in local culture history. 
Our focus will be on West Fujian - a mountainous area known as Minxi 闽西— located about $200 \mathrm{~km}$ from the seaside city of Xiamen, where three provinces share common borders: Fujian, Jiangxi, and Guangdong (min yue gan 闽粤赣). Geographically it lies within the basins of the Ting, Yongding, and Jingfenxi rivers, the three main rivers of the region. Tingjiang is the longest river in West Fujian, running north-south in Fujian and ultimately joining the Hanjiang in Guangdong. It has many culturally significant meanings, not least the fact that it is also known as the "mother river" (mujiang 母江).

Methodologically, we have considered the main historical sources that fulfil the function of identifying the three points that frame the placement of Hakka women (migration, education, and womanhood), namely: missionary sources of the 19th century; primary scholars in Hakka studies, most of whom are, in fact, Hakka themselves; local Gazetteers; Minxi Hakka family and genealogy records (jiapu and zupu); and literary sources on Hakka women. We have also taken into account folk narratives and beliefs and material culture elements collected in Minxi Hakka village fieldwork between 2014 and 2018, based on the premise that:

Official histories, dissenting histories, and the myths, festivals, theatre, and ritual of popular gods are all open to being interpreted as operations of historical signification and its celebration. (Feuchtwang 2001,5)

It is in this corpus that we are going to search for the paradigm of women in Hakka historiography.

\section{The Land and the People}

The Hakka Kejia 客家 people belong to the Han ethnic group, officially a subgroup, ${ }^{1}$ the cohesiveness and identification of which, on both local and national and transnational levels, is strongly based on cultural and historical features, namely the historical waves of migration from central to southern China, the strong sense of rurality, and the perpetuation of a corpus of practices, beliefs and attitudes. Language also plays a central role, but, especially in this axiomatically migrating society, it is not the primary element of group identification. ${ }^{2}$

1 The Han ethnic group is divided into eight subgroups, and in addition to the Hakka the other seven are the Northerners, Wu, Gan, Xiang, Yue, Northern Min (Minbei), Southern Min (Minnan) (Zhang Shengyou 张胜友 (1948-2018) in An 2015,1).

2 There is no unified Hakka language. There are many different Hakka spoken languages, many of which are not reciprocally comprehensible. With the "Hakka revival" of the last few decades, there has been an academic trend to try and codify a common Hakka language. 
Minxi is considered "the cradle of the Hakka people", though it is home to other ethnic groups as well, such as the Minnan and the She-the last being the only local ethnic minority recognized as such by the central government. ${ }^{3}$ In the past two centuries, Hakkas from these villages and counties-historically known as bamin 八閩—have taken part in a global diaspora, while still maintaining strong links to their ancestors' land as overseas Chinese buaqiao (Lin 2006, 376).

As a group, the Hakka people's cultural boundaries are highly permeable, and they are known for their inclusiveness towards other groups and adaptability in new cultural and physical environments.

Moreover, the Hakka group displays a strong sense of belonging and cohesion, which makes individuals appear to be very unified from the outside, but greatly diversified from the inside. Hakka studies scholars refer to this as "plural unity" (duoyuan yiti 多元一体), borrowing the expression from Fei Xiaotong 1988 (Cai 2004, 73-77; Wu 2012), or “multi-bodied unity” (dati yizhi 大体一致) (Xie 2003). Their identity narrative coincides with the historical narrative of migrations, during which communities were formed and then settled in the different territories of South-East China and, starting from the 18th century, in South-East Asia, and, from the 19th and 20th centuries, in the world at large.

Hakka society, like rural societies in South China generally, is patriarchal; communities are characterized by a family structure composed of clans united by large-scale kinship patriarchal alliances, wherein marriages are exogamous, patrilineal and virilocal (Freedman 1958a, 1958b, 1970; Cohen 2005; Faure 1990, 2007; Hu, Huang and Zhang 2014 (2006); Brandtstadter and Santos 2009; Malighetti 2014; Bruckermann and Feuchtwang 2016).

The basic unit is the village, which is traditionally a single-surname settlement; but there are many examples of villages that include the union of different family groups. Hakka women have always been a reference point for the family and for the whole village - from which men of working age emigrated, and still emigrate today, in search of their fortunes, leaving the care of the household, elderly, children and fields to their wives and betrothed.

3 Recent demographic assessments show the presence of other provenances as well, such as the Hui, Miao, Zhuang, Manchu, etc.: a total of 14 ethnic groups, many of which concentrated in the Zhangping jurisdiction zone (Ceng et al. 2011, 12-42). The area is also home to others, mainly women, from foreign countries, especially Vietnam, Cambodia and Myanmar. 


\section{The Importance of History in a Migration Identity Narrative}

The first systematic studies on Hakka origins and history date back to the 19th century. Missionaries posted to South China were the first to show interest in the field, originally from a language standpoint, ${ }^{4}$ and subsequently branching out to anthropology and history. The Hong Kong-based bimonthly journal Notes and Queries on China and Japan, renamed The China Review: Or, Notes and Queries on the Far East in 1872, collected sinological essays as well as translations of classical and folk texts. From 1867 onwards, the Rev. Ernest John Eitel, of the Basel Mission and the London Missionary Society, later second editor-in-chief of The China Review, ran a column entitled Ethnographical Sketches of the Hakka Chinese; in 1873, he was the first to publish a tentative outline Hakka history in a western language, An Outline History of the Hakkas, which was held in high esteem by latter-day historians. He places the origin of the Hakka clans in the 3rd century BCE, setting them geographically in the Northern Plains, and states:

It is but quite lately, through the Tai-ping rebellion, that the Hakkas have obtained a place in the annals of the Middle Kingdom. Before that time no historian ever mentioned them as far as I am aware. (Eitel $1873,160)$

Indeed, to this day no earlier mention of this group as "Hakka" is known. The main sources for Eitel's historical outline are the family records held by the various clans (jiapus and zupus), oral traditions, songs and ballads. He recalls their errant wanderings from the North-Shandong, according to him-to the South, on account of persecutions. According to Eitel's reconstruction, the mountains on the border between Fujian, Jiangxi, and Guangdong came to be inhabited from the Tang dynasty onwards. At the beginning of the Ming era, he says, an "overwhelming" number of Hakkas fled from this area, for reasons unclear to him, and established themselves in the Canton area, in Jiaying 嘉 应. From this moment on, Jiaying Prefecture began to feel the influence of the Jiangxi and Fujian cultures. From here onwards, Eitel devotes all his attention to the vicissitudes of the Guangdong Hakkas. From Qianlong's reign on, he states, the Hakkas gained more and more credibility on the part of the central government, who considered them more reliable than the Punties (punti is the Cantonese pronunciation of "native" bendi 本地) and the Minnan (AKA

4 Hakka is considered one of the Han group of dialects. According to Yuan's (1983 [1960]) classical taxonomy, the Han groups are: 1. Northern languages; 2. Wu; 3. Xiang; 4. Gan; 5. Hakka; 6. Yue; 7. Min. The more recent classification by Zhang Shengyou (fn. 1) divides the Min group into Northern and Southern Min. 
Hoklo or Ho-1o). Many of them were enlisted under the Eight Flags, where they gained prestigious positions after passing the relevant literary and military examinations. The Hakka, moreover, defined as "simple-minded but stalwart", led the Taiping Rebellion: Hong Xiuquan 洪秀全 (1814-1864) came from a Hakka family, and so did the other two Taiping "sovereigns". The prowess of Hakka soldiers was also recognized by the English and French, who called them the "Bamboo Rifle Corps". The war between the Hakkas and the Punties, which heavily impacted southern Guangdong between 1855 and 1868, engendered a further Hakka migration from the Canton territory in every direction, as well as overseas. The survivors roamed the countryside, some took up banditry, others took shelter in mountain areas, where they found refuge and built fortresses to defend themselves from Punties and wandering bandits. ${ }^{5}$ Eitel defines their settlements as “Little Republics” (ibid., 163). Xu Xuzeng 徐旭曾 (1751-1819), the High Steward of Canton, in an attempt to mediate and bring peace to the two groups, awarded the Hakkas a per capita sum of money to induce them to go and farm remote lands in Jiangxi, Hainan, Macao, and elsewhere. In the fourth issue of The China Review, Ch. Piton integrates Eitel's historical information in a note "On the Origin and History of the Hakkas", adding the detail of a settlement stop in the East Fujian town of Shibi 石壁, in Ninghua jurisdiction (Piton in Dennys 1873, 222-26); this is still considered by Hakka studies historians as an important waypoint for the migration course that, during the Southern Song period (1127-1279), brought the Hakka clans to Fujian (Zheng 2009, 13, among others).

As one may already infer from these early narratives, the migration history of family groups from central China to the south stands out as a primary factor in group awareness as well as an important factor of cohesiveness. The emergence of the term Hakka (kejia 客家, ke 客 meaning “guest”), is itself an historicized concept, related to the migration process.

The abovementioned $\mathrm{Xu}$ Xuzeng was government delegate for Hepingxian, Guangdong, sent to deal with the conflicts that had arisen between Hakkas (keren 客人) and Punties (bendi) in 1808 (Xu 2016, 16-17). Xu was impressed by the powerful group awareness that distinguished the Hakkas from the natives:

土自土，客自客.各自保留特色。

5 In Guangdong and Southern Jiangxi, the traditional Hakka dwelling, the tulou 土楼, is built like an actual fortification, whereas in Fujian, where the Punti-Hakka conflict was less violent, the tulous, many of which have been preserved to this day, are less martial, more elegant, and more refined in architectural details. On the architectural features of tulous in different areas in Minxi, Jiangxi and Guangdong, see Xie (2009, 80); An (2015, 292-314); Huang (2020). 
Natives are natives, guests are guests, each has its own peculiarities. (ibid., 17) ${ }^{6}$

Slightly after Xu, Huang Xiangtie 黄香铁 (1787-1853), in the nine chapters of his 1880 A Journey to the Cave, ${ }^{7}$ describes the life of Guangdong villages, their territory, education, customs, local history, dialect, forms of art, and religious beliefs. In the chapters dedicated to the language he refers to a group of people who spoke a different language, one that comes from the outside, spoken by “guests" kehu 客户 that had populated the area since the Southern Song, and had come from the Central Plains (Lin 2015, 199-223). Originally, the term we use for Hakka today was associated with migrants "on the run" that interfaced with local populations in varying degrees of conflict, as in the fierce Guangdong Hakka-Punti 1855 war. Their relations with central authority were not organic, and they did tend to unite into groups where kinship was the main binding force. In the chronicles of other populations where the Hakkas settled, there is a derogatory connotation attached to the name that implied not only banditry, but also destitution and poverty. In reference to the Hakka people (kemin 客民), they are called Hakka bandits (kefei 客匪), mountain brigands (shanzei 山贼), gentle brigands (raozei 饶贼), Zhangzhou bandits (zhangkou 漳寇) (Xie 2009, 79). The Hakka gentry (keshen 客绅) are called rebel chieftains (nifan shou 逆反 首) or bandit chieftains (zeishou 贼首) (Constable 1996, 69). The Hakka people's effort to counter this negative stigma has been a major driving force towards an upwardly redefinition of their status.

In 1933, Hakka historian Luo Xianglin/Lo Hsiang-lin (1906-1978), in his Study on Hakka Origins, ${ }^{8}$ provided the vast Hakka family with academic dignity within Chinese and foreign scholarship, and set the theoretical framework for the definition of Hakka as an "ethnic group" (Ge 1999; Chen 1996; Fang 2012). Luo's enquiry was based on data collected from various historical sources, first of all the family books (jiapu) and genealogy books (zupu) of Hakka lineages in different areas of South China, as well as on previous studies in English and Chinese. ${ }^{9}$ According to Luo, in the migration process, the Hakkas achieved integration in local communities "like fish in a lake" (Luo 1992, 1), and were no longer distinguishable from the latter.

\footnotetext{
6 The Chinese-English translations here and below are mine.

7 石窟一征. Published after his death, by his son.

8 客家源流考. In this analysis I refer to the reprint published in 1992 by Shanghai Wenyi Chubanshe, and to the more recent edition (Luo 2018).

9 Among which George Campbell's 1912 The Origin of Hakka Migrations; Huntington's Character of Races and Maciver's Hakka Dictionary. These and others quoted in Luo $(2018,21)$.
} 
His main contribution was to single out five phases in Hakka migrations, for each of which he outlined distinct characteristics. The first phase would go back all the way to the 4th century CE, when, after the invasion of the five nomad peoples-Xiongnu, Xianbei, Jie, Quang, Di-the Western Jin dynasty (265-316 CE) moved southwards and founded the Eastern Jin (317-420) (Luo 2018, 40). Even in this early phase, the groups that fled the northern plains under the influence of the nomad invaders split up between those who embarked on various small-scale migrations in all directions, heading for zones close to the lands they were escaping from, and those who moved further away, southwards, until they reached Fujian as well as central and southern Jiangxi, always within Han-populated areas. It is estimated that this included about one million people, one sixth of the total population.

The second phase dates to the end of the Tang dynasty (618-907), when people escaping the territories affected by the turmoil of Huang Chao's (874-888 $\mathrm{CE}$ ) revolt headed for far-away lands inhabited by non-Han populations (ibid., 46-47). These settled mostly in the Min area of Ninghua, Tingzhou, Shanghang, and Yongding, and in the Southern area of Ganzhou in Jiangxi (Gannan) (ibid., 49).

The third, more massive exodus took place under the Song (960-1279), especially during the 12th and 13th centuries, during the Mongol invasions, when many came to colonize the mountain areas on the borders between West Fujian and East Guangdong, and concentrated especially in the Tingzhou 汀洲 territory (ibid., 49-58). This triangle is considered today the area which has maintained the "original" Hakka culture. Luo points out that in this later period there was a very large-scale mingling of Hakkas with the local populations, especially She minorities; this is also confirmed by the data on population increases in the areas concerned.

The fourth migratory phase took place at the end of the Ming dynasty (1644). Luo associates it with overpopulation and an imbalance between cultivable land and the number of inhabitants. In this phase, migrations affected eastern $\mathrm{Si}^{-}$ chuan, Guangdong, and western Jiangxi, as well as Hunan (ibid., 58-60). At the same time, moreover, many families, wishing to escape the turmoil generated by clashes for the imperial throne between the Ming and Qing, became followers of the warriors of the Zheng family, well known for the deeds of the hero Koxinga [Zheng Chenggong 郑成功 (1624-1662)], and faithful to the Ming-and undertook the settlement of Taiwan (ibid., 61). From the economic standpoint this period is characterized by a diversification in production activities, which, from this time onwards, opened up to four well-defined categories: animal husbandry, 
farming, mining, and trade over land and on the seas. The population increase in the Yongding area brought problems related to overpopulation-epidemics, social disorders, and religious struggles - and the people were also plagued by natural disasters (Hu 2009 [2006], 7).

According to Luo's periodization, the fifth phase, dating from about 1862 onwards, was contemporary to himself, and described the Hakka migrations towards Guangdong, Taiwan, and Hong Kong, as well as to other areas in western central China, as ongoing phenomena, in the course of this process Meixian 梅县 and Shantou 汕头 in Guangdong became important harbour cities for Hakka routes towards East and South Asian countries (Luo 2018, 63). ${ }^{10}$ This is the same period in which the Hakkas begin to be noticed by Westerners, who remark on their linguistic peculiarities and their conflicts with the Punties:

The great predominance of the Hakka element on the Kau Lung peninsula would seem to indicate Hakka aborigines for Hong Kong itself. Nevertheless there are old shopkeepers in the villages who profess to remember the occupation and say that each village has always had a distinctive character. Thus Shaukiwan has always been Hakka, but Wongnaich'ong always Punti. The villagers of Little Hong Kong indignantly deny that they are Hakka, but "their speech betrayeth them". They may be Punties, but half their words are Hakka. (L. P. C., Notes and Queries No. 7 in Dennys 2020, 108)

The main causes of this last migration, according to Luo, are to be seen in overpopulation and competition with local people, but also in the wish to better one's social and economic position by conquering new territory. He also quotes Eitel's remark about the High Steward of Canton paying the Hakkas a per capita sum to induce them to move to new territories (Luo 2018, 62).

Moreover, Skinner (in Leong and Wright 1997) is of the opinion that the success of Luo's historiographic approach lies in the fact that he was able to give scientific credence to an oral narrative hitherto internal to a group who already recognized

10 Many, driven by circumstances, decided to emigrate voluntarily in boats known as "floating jails", in order to go and work in foreign countries as coolies (kuli 苦力). Between 1881 and 1930, the estimate is that more than eight million people went to seek their fortunes overseas. After boarding in Fujian or Guangdong ports, immigrants would reach Malaysia and from there get shipped away to destinations in all five continents. About $70 \%$ of them were bound by manual labour contracts which fell just short of slavery. The main destinations were British and Dutch colonies, but also America and Europe (An 2015,709-11). Those that were wealthy enough to carry out independent projects headed mainly towards Indonesia, Malaysia, Singapore, the Philippines, Thailand, Vietnam, Laos, Cambodia, Myanmar, and India (ibid., 715). 
itself as composed of migrants and settlers in various South China territories, and claimed a common origin from the Central Plains. ${ }^{11}$

With Luo comes the importance that Hakka studies attribute to the lineages of family descent, starting from the genealogy books; this was also held valid by Western scholars, i.e., Leong (1997), Freedman (1958a; 1958b), and Constable (1996). Contemporary historical studies enrich Luo's periodization with elements deriving from the analysis of other indirect sources, studies on demographic flows in local gazettes, on the flows of goods, and on exchanges with neighbouring populations (Minxi Hakka Friendship Association 2013; An 2015; Cao 2018).

Erbaugh's outline of the Hakka people's history, published in 1992 in The China Quarterly and again in Blum and Jensen (2002), highlights the formation of Hakka communities through the lens of historical linguistics, and concludes by underscoring the importance of Hakka languages as a feature of cohesion among various groups, both in China and the diaspora. She also introduces the conceptual paradox of "Hakka obscurity and high political position". Again, in Erbaugh (2002, 188) gender equality, solidarity, mobility and military prowess are highlighted as key strong points of Hakka culture and history. Cohen $(1968 ; 1996 ; 2005)$ tends to analyse Hakka culture as strongly linked to the linguistic evolution of Hakka dialects, otherwise connoted as an indistinct whole: spatially connecting millions of people in China and the diaspora, and chronologically "fossilized" in a sort of unchanging, conservative container. This idealized vision of Hakka culture was received and furthered by many scholars in early Hakka studies. Constable (1996) collects many of these, reflecting the older attitude, while at the same time introducing a new approach: that of the importance of locality in historical and anthropological studies.

The vision of "unity in plurality/plural unity" (duoyuan yiti) put forward by Fei Xiaotong (1988) became an important way to describe not only Chinese civilization as a whole, but Hakka culture itself. Starting from the mid-1990s—which saw a revival of practices and beliefs that had been placed within the framework of superstition from 1949 onwards, and as such had been provisionally erased from memory - what came to the fore was the local dimension.

The innovative and complete ethnographic research on Hakka studies produced by a team led by John Lagerwey for the Hakka Research Center at Jiaying University in Meizhou (Guangdong Province) collected works by scholars from South China universities and has published-so far-a 30-volume series: Traditional Hakka Society (Kejia chuantong shehui). In this massive publication, the aim is to

11 "These men and others identified and codified Hakka values and forms and propagated a Hakka cultural past with a view to enhancing the depressed social status of a despised people." (Skinner in Leong and Wright 1997, 30) 
draw the map of the various nuances within the different people who recognize themselves as Hakka. The series includes articles and monographs written by local experts invited by Lagerwey to be active informants on their own culture.

As seen so far, Hakka historiography confirms that the migration narrative is pivotal for Hakka community awareness.

\section{Women in Hakka History}

The centrality of women in Hakka group awareness is noted by both foreign and Chinese (Hakka and non-Hakka) scholars:

Women have become, in a sense, objectified as a symbol of Hakka identity, an embodiment of Hakka qualities, and the basis of a Hakka claim to a rhetoric of equalities. (Constable 1996, 119)

Moreover: "Hakka women embody Hakka culture"12 (Wu 2011, 16), and "There are people who consider the Hakka woman as a representation and a symbol of Hakka culture"13 (Xu 2016, 11), in continuity with Luo Xianglin's (1933 [2018]) earlier remarks. All Hakka scholars single out Hakka women for never having adopted the custom of foot-binding. However, Hakka women still had to submit to the rules of their main occupations (si tou si wei 四头四尾): “They mind the field and the soil, the pot and the hearth, the needle and the thread, the home and education"14 (Xie 2005a, 210).

Western scholars of the 19th century were also struck by the particular characteristics of Hakka women, and contributed to the coalescence and consolidation of the link between the gender aspect and Hakka identity.

In On the Origin and History of the Hakka, Ch. Piton reports a village foundation folk story in which a woman plays a central role. It is the legend of "Kudzu village" (Geteng keng 葛藤坑), also reported by Luo $(2018,65)$ and still alive in Fujian as an example of female virtue. The story is purported to go back to the time of Huang Chao's revolts, in the 9th century CE. It is said that in those days a fugitive woman was bringing two children with her, the older one on her shoulders, while the younger one followed on foot. Huang Chao himself saw her and asked her why she was carrying the eldest and not the youngest. She answered that the eldest one

\footnotetext{
12 客家妇女是客家文化的典型体现.

13 有人把客家妇女视为客家人的代表和象征.

14 田头地尾; 锅头灶尾; 针头线尾; 家头教尾.
} 
was her nephew, and since she had heard that Huang Chao kidnapped children, she did not want him to be taken away. Since the youngest was her son, she could keep him on the ground. Huang Chao understood, and allayed her fears. He told her to go back home and put a branch of Kudzu (Geteng 葛藤, Chinese arrowroot) on her front door. It would have been a symbol for all the rebels not to touch any home with a Kudzu vine at the door. The village homes were thus protected by Kudzu branches, and that is why the village was then called Geteng Village. In this story, the female virtue of holding back on her own personal interest and bestowing favour on a son of her brother-in-law instead of her own spreads out to the whole village and protects it. According to $\mathrm{Ch}$. Piton, this is the legend of the origin of the village of Shibi, in Fujian Ninghua county, currently considered the door to Fujian Hakka settlements. Other village foundation legends report the presence of female characters, such as those of the villages of Tianluo Keng and Xiayang in Yongding district. Moreover, when village founders are celebrated, the male founder is generally venerated together with his wife, as in Chendong 城东 village's Si yue ba 四月八 festival in Yongding. In Yanpocun 严婆村 village, in Changting 长汀, two women, and no men, are credited as founders of the settlement. These are only some examples of historical—or semi-historical—women linked to village foundations who did not enter the official books of history, but were transmitted in the local collective memories and in material culture.

At the dawn of the Hakka historiographical tradition, the Westerners stationed in Hong Kong observed Hakka women and distinguished them from the other, mainly Punti, womenfolk.

It is an interesting question, too, why the entire prostitute class of Hong Kong should, apparently without any exception, be Punti. I believe that the Hakka women are more domestic, laborious and "keepers at home", and more faithful; while the Punti women are fond of finery, fickle, frivolous, and more set on gain than their simpler Hakka sisters. (L. P. C., Notes and Queries No. 7 in Dennys 1867, 108)

In his seventh chapter, dedicated to "Hakka Nature", Kejiade texing, Luo Xianglin speaks about Hakka women, and defines them as "hardworking and resistant to hardship” (jianku nailao 坚苦耐劳), “extremely independent and self-sufficient” (zui zizhong zili 最自重自立). He also states that they make a sizable contribution to family life and to the state, and are appreciated by all. He furthermore quotes from an article dedicated to Guangdong Hakka women, "Notable Hakka Women from Guangdong", ${ }^{15}$ published in the biennial journal

15 值得注意的广东客家女. By Xin Geng 心根; Funü gongmin 妇女共鸣 No. 2/2, pp. 22-30 February 1933. 
Funü gongmin 妇女共鸣. ${ }^{16}$ This article recounts the position of Hakka women in the family and society, their economic and production roles, their relationships with their husbands and their attitudes towards life. It also referred to the custom, well-attested in all local historical sources, according to which men emigrated far away (the recurring expression is panbai 潘海), while women were left in the village with the elderly and the young.

When men emigrate and do not return for more than ten years, as is very often the case, they [the women] manage easily. If they have fields to farm, they farm them; if they do not, they will rent a few mu of land, as much as necessary to feed the family all year round. (Luo 2018, 191)

The woman left at home alone, in the traditional rammed-earth tulou that shelters all the members of the family, became its de facto head: she organized the fieldwork, administered the family finances, and also took care of construction work to terrace hill slopes and build roads.

When women have to farm, they farm. When there is no farming, in the day they take goods to the market, or do some tailoring jobs for third parties, whereas in the evening they weave at the loom ... Thus, not only are they able to provide for the family's basic support, but manage to make what is needed for their sons and daughters' education. The Hakka woman is the mainstay of the family. (ibid.)

The way the author highlights the role of the Hakka woman in society-whether as a participant in the collective life of the village, or in terms of her skills-is fairly remarkable:

She also has an important role in society. She shares in the costs incurred for annual feast-days, fertilizer, and buying farm appliances, and partakes in the economy by making money circulate and depositing her savings. She is fully competent about everything that regards traditional farming practices, in which she is quite knowledgeable and experienced, and this allows the Hakka woman to expand economic activity and attain a higher social status. (ibid.)

However, throughout her life, a Hakka woman's most important identity role was above all carried out in her family:

16 The journal founded in Shanghai in 1929 by the Guomindang's Women Union, and published until 1944. 
The Hakka woman is the most important reference point for the whole family, that relies on her for its cohesion: her children depend on her for their education, her husband for support in his activities, and all of Hakka-kind for the continuation of the lineage. (ibid.)

Luo also adds that Hakka women:

do not use makeup, do not bind their feet or bust to attract men's attention, do not give prominence to their shoulders or breasts.... They are frugal in dress and meals, save food and money for their family and for when their husband returns home. (ibid., 192)

He also highlights the jianfu 健妇, the tireless and strong female model that is traditionally handed down as a feature of Hakka cultural singularity:

The Hakka woman is very proficient in her work, she wakes at daybreak, goes to bed late at night. In the daytime she doesn't shirk from any chore ... Even when she is advanced in years she keeps up her commitment to household affairs and farming, she takes an interest in every family member, is a good example, is never idle, just like when she was young and strong. (ibid.)

What one must add here is that the paradigm of Hakka woman brought about by the early Hakka historians is a founding element of Hakka identity. In historical and literary sources, Hakka virtues attributed to women like diligence, strength, competence and dedication coexist with the idea that Hakka women's status is on equal terms with men's. In Hakka historiography, gender equality draws the (flexible) line between the Hakka and non-Hakka cultural frameworks. On the other hand, this gender equality paradigm is actually often disclaimed, perhaps right within the same discourse, by evidence showing exactly the contrary.

Female social subjugation was made clear in the official historical records, where they did not have the right to have a name, but were recorded, if at all, as "wife of ...". In the case of wife of a lineage founder, they were addressed to as "great-grandmother" (potai 婆太) and their name would appear in the genealogy books and on the memorial tablet dedicated to the ancestor cult with the honorific title of "deceased mother" (bi 妣). ${ }^{17}$ Even the exemplary women recorded in the gazetteers, despite the fact that they were distinguished for their virtue, chastity (zhen 贞), or moral

17 The definition in the Shuowen jiezi is: 歿母也從女比聲. For electronic version, see https://hanziyuan.net/. Accessed August, 2020. 
integrity (jie 节) towards their husbands—sometimes to the point of committing suicide (zhenlie 贞烈)—did not appear under their own name, but under the relevant male's family name and kinship relation. As a way of example, we can quote here the 31st Chapter in "Republican Era's Yongding Gazette", entitled Biographies of Exemplary Women Lienü zhuan 列女传 (Xu 2015, 727-91), thus echoing Liu Xiang's 刘 向 (79-8 BCE) classic Biographies of Exemplary Women, Lienü Zhuan 列女传. ${ }^{18}$

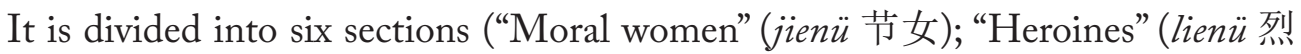
女) (corrected with the homophone "Exemplary women" (lienü 列女)); “Chaste wives" (zhennü 贞女); “Honourable ladies" (shuyuan 淑媛); “Good mothers" (xian$m u$ 贤母); “Centenarian ladies” (shoufu 寿妇). The entry line for every lady quoted is: "XX shi 氏 (original family name), XX qi 妻 (wife of XX)". Their personal stories, from 10 to 80 characters long, highlight their devotion to their families, and specifically their husbands, who in some cases they had not yet married (they were fiancées, weihunqi 未婚妻).

In general, after that of strength, the second paradigm that allowed women to enter the official historical records was moral virtue. Gazette data enable us to pinpoint this very significant feature.

In the 18th-century "Tingzhou Gazette" (Qing dynasty, reign of Qianlong) analysed in Xu (2011,115-18) the numbers of Minxi women listed were as follows:

Table 1: Exemplary Women in 18th Century local Gazette.

\begin{tabular}{|c|c|c|}
\hline Epoch & Virtues & Number \\
\hline Song dynasty & Chaste wives, moral women 贞, 节 & 186 \\
\hline Yuan dynasty & $\begin{array}{c}\text { Heroines for their chastity 贞烈 } \\
\text { (segregated or self-immolated) }\end{array}$ & 1 \\
\hline Ming dynasty & $\begin{array}{c}\text { Heroines for their chastity 贞烈 } \\
\text { (segregated or self-immolated) }\end{array}$ & 45 \\
\hline & Chaste wives, moral women 贞,节 & 720 \\
\hline $\begin{array}{c}\text { Qianlong era (up to } \\
\text { his 17th year-1772) }\end{array}$ & $\begin{array}{c}\text { Heroines for their chastity 贞烈 } \\
\text { (segregated or self-immolated) }\end{array}$ & 79 \\
\hline & $\begin{array}{c}\text { Chaste wives, moral women 贞, 节 } \\
\text { Heroines for their chastity 贞烈 } \\
\text { (segregated or self-immolated) }\end{array}$ & 720 \\
\hline
\end{tabular}

18 This is the earliest literary collection of biographies especially focused on women. Liu Xiang's Lienü zhuan initiated the lienü 列女 historical tradition as a part of official dynastic history. 
The data is also significant in the "Yongding Gazette-Republican Era" (Xu 2015, 727-92):

\begin{tabular}{|l|c|c|}
\hline Moral women & 节妇 & 626 \\
\hline Chaste wives & 贞女 & 30 \\
\hline Honourable ladies & 淑媛 & 23 \\
\hline Good mothers & 贤母 & 4 \\
\hline Centenarians & 寿妇 & 53 \\
\hline
\end{tabular}

As we can see from the data, women who segregated themselves or self-immolated to show their devotion to their husbands were greatly celebrated, even until recent times. This shows that the virtues linked to the subjection of women to family duties, to the $n e i,{ }^{19}$ were held in great honour until the modern age.

The moral paradigm links Hakka women to Hakka culture. This is what emerges from foreign and Chinese historians (all men) of the 19th and beginning of the 20th centuries: the Hakka woman historical narrative lines up with the culture narrative. In the second half of 20th century there is a large shift in such historiography, as Hakka women enter into the official records with a new identity, one which overlaps that of the tradition, without totally wiping it out.

In the following paragraphs we will see how the social construct is built in line with the "traditional" heritage, on top of which the paradigm of the Hakka woman enters into official history.

\section{The Traditional Heritage: The Moral Paradigm in the Hakka Woman's Social Construct}

At the basis of Hakka society lies the strong distinction between the women's realm and the men's realm (nannü zhibie 男女之别), and a sharp differentiation of roles. As Luo writes:

The (adult) men of the household might also take part in household activities, but their most important role does not lie there, it lies in society. ... Husbands, who do not know about household affairs, do not ask too many questions and their wives, on their part, are not pleased if they interfere with house chores. (Luo 2018, 191)

19 We will look at this concept of nei 內 in the following section. 
This division between what lies inside, nei 内, and what is outside, wai 外, is proof of the powerful link between Hakka culture and the classic tradition. The Neize 内 则 chapter of the Liji is one of the oldest sources. ${ }^{20}$ In Neize, 57 we read: "Men are positioned on the outside, women in the outside (nan ju wai, nü ju nei 男居外, 女居内).” And in Neize, 14: “Men do not talk about what refers to the inside (of the household), women do not talk about what refers to the outside (nan bu yan nei, nübu yan wai 男不言內, 女不言外).”

The Neize establishes the norm for male/female differentiation nannü zhi bie (男 女之别), as it emerges in the separation of spaces and spheres of action, of inside vs. outside (nei/wai 内/外), of studies, of ceremonial performance, and even of clothing, as well as of family relationships.

The gender construction stemmed from the Neize is transmitted throughout the multifaceted Confucian tradition and it flourishes in the Lixue School, from which the Hakka culture draws heavily.

Many Hakka scholars agree in identifying the outline of the Hakka women's social construct within the ethical framework of the Neo-Confucian Lixue School. Zhu $\mathrm{Xi}$ 朱喜 (1130-1200), whose reformed Neo-Confucian line of thought is specifically known today as the Fujian School (Minpai 闽派), was a Fujian native from Youxi County (currently part of the Sanming jurisdiction), and spent a long time in Jianyang and Yanping, always in Fujian, where he held numerous lectures and attracted many disciples (Xie 2002, 97). But the great diffusion of Neo-Confucian principles took place later, during the Ming period (1368-1644), that is to say, in the time during which, mutatis mutandis, West Fujian settlements consolidated into the forms that they still have. In 1516, Wang Yangming 王阳明 (1472-1529) was sent to South Jiangxi, and thence travelled to the Fujian Hakka and She (畣) areas, to rebuild social order after the dramatic disorders that had characterized the area in the first half of 16th century (Liu 2013,126). In the political process of encouraging the local formation of alliances, aimed at facilitating the relationship between local and national government, Wang Yangming promoted an alliance, the Nangan xiangyue 南赣乡约, among Jiangxi, Fujian, and Guangdong: this was also an ideological tool, meant to promote morality (Xie 2005b, 7; Liu 2013, 169). Wang not only introduced the Baojia 保甲 system, ${ }^{21}$ but also decreed that each family was to

20 This is the 12th chapter of the Book of Rites ( 3 rd century BCE), one of the five chapters of the Confucian canon. It marked the distinction between womanhood and manhood through the definition of different rituals, li. Legge (1885) translates Neize as Family Conducts, whereas Ebrey (2002) translates Domestic Regulations. Luo's (2017) translation is Ceremonies about Management of Families. The Chinese term Neize will be used here.

21 Ten households make a Pai 牌, presided over by a Paitou 牌头. Ten Pai 牌 are a Jia 甲, presided over by a Jiazhang 甲长; ten Jia 甲 are a Bao 保, headed by a Baozheng 保证. Several Bao 保 make up an alliance and form a Lian 联, presided over by a Lianzhang 联长 (Leo and Dai 2000, 46-47). 
provide an education in Confucian values for all its members (Xie 2005a, 116), including women. The Hakkas, in their striving for social redemption and well-aware of their provenance from separate and distinct families, enthusiastically endorsed the directives of the alliance, and expressed their loyalty to the sovereign.

Here we can try to answer to the following question: to what extent was the adherence to Lixue ethics able to redeem the migrant communities of kejia and raise them to the highest social level?

We have to consider that the settlers occupying new territories were in continuous interaction with local populations, among which the only officially recognized local minority was the She. The She practiced serpent cults and other nature cults, they were mainly hunter-gatherers, knew little agriculture, and their code of conduct was not considered to be compatible with that of the Han. The "Tingzhou Gazette", describes them in the following terms: “... when husband and wife have sex and a child is born, they drop him on the naked earth, wash him in a spring, without avoiding wind and sun." (Zeng 1748, chap. 41, 142).

Cult, ethical and ritual differences were important features to distinguish one's own group from "barbarians", man 蛮. The Lixue, as a strong, dominant ideology, provided a useful instrument with which to establish the impulse to improve one's collectivity and social mobility. In this ethical framework, the separation between the male and female worlds (nannü zhibie) became an imperative, just like a wife's chastity and fidelity towards her husband (zhen). Generally speaking, the social hierarchy (wulun 五伦), of mengzian origin, ${ }^{22}$ became the prerequisite for the construction of personhood, and it led to the Threefold Obedience and Four Virtues (san cong side 三从四德), ${ }^{23}$ the basis for women's ethics. Moreover, the rituals that Zhu Xi codified in his Family rituals (Jiali 家礼) became the norm in local communities, entrenched as shared cultural standards. Xie (2005d, 47) reports

22 In Mencius one reads: 聖人有憂之, 使契為司徒, 教以人倫: 父子有親, 君臣有義, 夫婦有 別, 長幼有序, 朋友有信. father-son, ruler-minister, husband-wife, big brother-little brother, friend-friend. (Mengzi, Teng Wengong, Shang: 4)

23 The rule of the "Threefold Obedience" (to the father, to the husband and to the son) appears in early Confucian texts, such as: The Book of Rites-The Great Suburban Sacrifice (Liji-Jiaotexing 礼记 - 郊 特牲); Liu Xiang's Biographies of Exemplary Women-Maternal Rectitud-The Mother Instructor of Lu (Lienü Zhuan-Mu Yi-Lu zhi mushi列女傳-母仪-鲁之母师); Ban Gu's Comprehensive Discussions in the White Tiger Hall (Baibutong 白虎通). The Four Virtues for women (si de 四德) appear in The Rites of the Zhou (Zhouli-Tiangong Zhongzai 周礼-天官冢宰: 131) as Women's Ethics, Women's Speech, Women's Appearance, Women's Works (fu de, fu yan, fu rong, fu gong 妇德、妇言、妇 容、妇功); they are explained in more detail by Ban Zhao (45-115 CE) in her Admonitions for Women (Nüjie 女诫), where the author described them in the 4th chapter "Women's Conduct" ( $f u$ xing 妇行). On the textual construction of a womanhood based on the submission of women to men, see Rosenlee (2006), and Ardizzoni (2020). 
that in the “Ninghua Gazetteer 宁化县志” one reads: “Capping, wedding, funeral, ancestor cult ceremonies must all be held in respect of $\mathrm{Zhu} \mathrm{Xi}$ rituals." ${ }^{4}$

The Lixue School emphasized the centrality of the patriarchal family as the core of society. As Wang $(2003,321)$ puts it: "The family [...] originates with oneself and extends to others. Nothing comes before the family." Within the family, women were framed within the formula of the Three Obediences and Four Virtues from which the idealized figures of daughter, wife, and mother originated.

In a society devoted to the lineage's ancestor cult, in which the transmission of power runs along patriarchal bloodlines, male offspring are essential, and this greatly affects a woman's position in society and generates her contradictory position within the family. Subjugated to the imperative of producing male descendants, she is framed within the family's reproductive role- a role which has been preserved even in modern times-but placed in a position of social inferiority within society. The quest for progeny emerges in the traditional practices of invocation for a son (qiuding 求丁), made to female (especially Guanyin) or male (Guangdi Gong, Jixiang Pusa, Baosheng Dadi, etc.) deities. Spirits shen 神, like the Pregnant Womb Spirit (Tai shen 胎神), or natural deities like trees, mainly hibiscus around which pieces of red paper or cloth are tied, or revered stones, are honoured with offerings of oil, tea, candy, incense, and so on; otherwise amulets, diagrams, magic spells may be used. ${ }^{25}$ This is why many female deities are worshipped in Hakka rural villages, and a statue of Guanyin is always placed in a niche in the main hall in every tulou: to call for the birth of sons, or to protect the newborn ones. In the Minxi mountain areas, women, before the family planning laws introduced in the Reform period by Deng Xiaoping, would have on average 5 to 12 children. Even after the law took effect, many babies, especially girls, were not officially recorded with the register, and were abandoned, sold, or otherwise disposed of. ${ }^{26}$ The disparity between a man and woman in the Hakka tradition is commonly recognized, and already marked birth. In current linguistic use, giving birth to a boy is referred to as tian ding 添丁 (Fang et al.2012,34), whereas a girl's birth is indicated as ban ding 半丁, a "half person". These common modern

24 冠、婚、丧、祭, 一遵朱子之书.

25 Zhou Jinshui $(2018,538-44)$ highlights all the customs and rituals that even nowadays must be held in the perinatal period: devotion to the gods and spirits, blessings on the labour room and on the woman in labour, and the taboos related to labour and to the post-natal period. Any mistake in these rituals may have negative consequences for the newborn or mother, in the short or long run. Fang $(2012,74-75)$ thus states that when a woman finds out she is pregnant, the family will go to the local Guanyin temple to ask for protection.

26 Eitel reports that: "The proportion of females killed immediately after birth is generally estimated by Hakkas to be about two-thirds of the whole number of females born.” (Eitel 1867, 98) 
sayings come from the ancient literary tradition. “Jewel” (nongzhang 弄璋) for newborn boys and “tile" (nongwa 弄瓦, indicating today a small ceramic object, or tile) for newborn girls are still living terms in the Hakka-speaking area. These come from The Book of Songs (Shijing) verse: "when a boy is born, one says that one has a jewel in one's hands; when a girl is born, a ceramic tile", and this line has been transmitted in the Confucian tradition through Ban Zhao's Admonitions for Women, Ch. 1:

\section{古者生女三日，卧之床下，弄之瓦砖。}

In ancient times, when a female baby was born, after three days she was put under the bed to play with a ceramic tile. (Chen 1992,6)

A few days after a child's birth, offerings in the ancestor temple or to the Tai shen altar are made to guarantee the newborn's health (you zi 佑子). If a boy, red rice balls shaped like turtles are offered, if a girl, the rice balls are shaped like peaches. It is important for the mother to follow the isolation period (zuo yuezi $i$ 坐月子) of 30 to 40 days after the child is born.

Hakka community ritual practices and social values, especially from the 16th century onwards, were configured on the one hand as faithfulness to Wen 文, the official, traditional literary culture of the Lixue School, but on the other as faithfulness to $W u$ 武, martial culture, through which they expressed their loyalty (zhong 忠) to imperial power-basically the Ming. During the Qing period, however, Hakkas showed their support for peasant revolutionary rebellions such as the Taiping, and, finally, from the 1920s onwards, their endorsement of Mao Zedong and his establishment of the first Soviets, throughout the Long March and the rest of the 20 th century. ${ }^{27}$

By way of conclusion: the complex of Hakka lineages is not ethnically defined, but is marked by the adherence to a shared culture, and individuals, often distributed throughout non-adjacent territories, often do not even speak Hakka. What unites the Hakka community is its history-the memory, continuity of descent lines, preservation of practices, beliefs, and actions, along with certain techniques related

27 The ideals of $W e n$ and $W u$ are expressed in the cult of local deities found in myriad rural altars throughout the Minxi territory: Wenchang 文昌 God of Literacy, Kuixing 奎星/鬼星 (大鬼夫子, 大魁星君) The Big Dipper, God of Examinations, and Guan Yu 关羽. The last of these is considered the God of War and is worshipped all over China, as well as in Taiwan, Hong Kong, Japan, and South East Asia. He is known also as Guangong 关公. Guanyu/Guangong, represents loyalty to family and lineage (Hu 2009, 228). The earliest Wen temple was built in Tingzhou fu in 1160 . In Yongding it was built in 1479 (Zhang 1994, 820). 
to the body (Mauss 2002 [1934]), ${ }^{28}$ handed down from one generation to the other, are the features that supply the individual with the means for self-identification within the group. In the process of constructing a society as distinct from that of native populations, and in the search for a cohesive bond for that cultural group, women held and still hold a central role. In the following paragraphs we shall see how the transmission of educational values linked to Wen has contributed to the construction of a binary gender society, wherein the multifaceted nature of Hakka women plays a primary role in its history.

\section{The Transmission of Ethical Values: The Paradigm of Education}

Education is highly valued among the Hakkas, where folk sayings celebrate the importance of schooling. In the Zengguang Xianwen 增广贤文, ${ }^{29}$ a Ming epoch $c i$ 詞 ballad which was widespread in the Hakka communities as a popular mountain-song (shan-ge 山歌), the saying goes: "Raising a son without educating him is like raising an ass, raising a daughter without educating her is like raising a pig." 30 Moreover: "No matter what one's poverty or troubles are, one must make it so that children study, even at the cost of selling the latrine jar" (ibid.). ${ }^{31}$ Study is linked to the perpetuation of family: "He who does not study has no wife" (ibid.). ${ }^{32}$

The importance attributed to education is recurrent in many features in Hakka villages: cults, practices, sayings, and customs, and not least in the willingness of successful Hakka migrants abroad to establish local schools for farmers. ${ }^{33}$ This was true also in the past, when every well-to-do family's tulou had its own private school, the shuyuan 书院, or sishu 私塾, for its offspring. In Zhongchuan village, a primary school was founded by the members of the $\mathrm{Hu}$ 胡 clan in 1670 , to

28 "Les façons dont les hommes, société par société, d'une façon traditionnelle, savent se servir de leur corps" (Mauss 2002 [1934], 5). Marcel Mauss offers a fourfold classification: birth and midwifery techniques, childhood techniques, adolescence techniques, adult life techniques (ibid., 14-20).

29 See http://www.millionbook.com/gd/y/yiming/000/003.htm. (Accessed July 10, 2020). It collects many references drawn from the above-mentioned tradition, showing a continuity with the segregationist ideal of the Neo-Confucian ethics prescriptions for women prescribed by Sima Guang, Zhu Xi and the Lixue School.

30 养子不教如养驴, 养女不教如养猪.

31 家再穷, 人再苦, 卖屎缸, 也要供孩子读书.

32 不读书, 无老婆.

33 There are many examples of this. Among the most distinguished ones, we may quote here $\mathrm{Hu}$ Wenhu 胡文虎 (AKA Aw Boon-Haw, 1882-1954), founder of the Tiger Balm brand, who set up and subsidized more than 300 schools in China and over 40 abroad, (see An 2015, 739-41; Xu 2016, 42-47; Hu 2019, 33.) His daughter Hu Xian 胡仙 (AKA Sally Aw, born 1932) is also known for her philanthropy in educational projects. 
prepare candidates for imperial examinations (Li Zhou in Leo and Dai 2000, 104). A private teacher was hired, jointly paid by all the members of the lineage and sub-lineages. The students - boys and girls alike-did not pay fees, but regularly offered gifts to the teachers, mainly vegetables or other food (ibid., 94-95). Deserving students were rewarded with collective scholarships, awarded by the whole village, with honour rolls exhibited in the family temple room, or in other collective spaces.

In order to honour those who had acquired special merits, celebratory poles were set up in the space in front of the village ancestor temple. In the Zhang family ancestral temple in Taxia, Zhangzhou jurisdiction, built in 1772, there are still 24 celebratory poles, 14 of which were erected between the year of the temple's foundation and 1902, the year in which the imperial examinations were abolished. In front of the $\mathrm{Hu}$ ancestral temple in Zhongchuan, 15 of 36 original poles remain, whereas in front of the Hongkeng Lin temple there are 24 poles, all reconstructed after having been knocked down in previous years. However, such poles were meant to celebrate the successful men of the lineage. The first instances of poles celebrating women date after 1978, when the custom was revived after having been outlawed during the Mao years. In fact, ten new poles were set up in front of the above-mentioned Zhang family temple in Taxia village after 1978, some of which are dedicated to distinguished women.

Gender education values were conveyed not only in formal instruction, but also in oral lore addressing everyone, including illiterate women. What follows is a ballad from the Hakka folk tradition, The Hakka Spouse (kejia buniang 客家哺娘詞), used to convey the core values of gender education. It is recorded in many genealogy books, and it is shown in the Hakka Family Prescription Museum in Hongkeng, in the area dedicated to Hakka women.

\section{The Ballad of the Hakka Spouse}

The young Hakka mother awakes at cockcrow, washes her face and combs her hair; she brews the tea, puts the soup on the fire, makes breakfast. Only then does the first light of day appear; she scrubs the floor with wine and water and fills the jars with clean water. Even before eating, she does the laundry, prepares food for the pigs and feeds them; meanwhile, the soup simmers slowly. First she takes care of the oven, then of the pots, everything is cleaned to a polish, then she takes to needle and thread, she sews and embroiders adroitly. Her man is away, he works and takes care of his business, some men have gone overseas, others to nearby villages; the woman stays at 
home and she has to be able to do everything, both small and great things, light and heavy labour. First of all, working in her field, on the land, cultivating fruits and grains, climbing up and down the mountains, moving fast, with silence in her heart. In her vegetable garden she grows greens, turns the grindstone, drives the pestle. She harvests bananas, cuts grass, sings mountain songs in a nightingale's voice, at the fourth hour she takes up work again, bearing the carrying pole by herself. When doing housework, she does not mind not eating well; when working in the fields she does not mind the wind and the snow. She always acts according to the rules, she knows who lies above and who lies below, she respects her parents-in-law. She holds her sons and daughters dear to her heart, she misses those who are far away, she instructs her husband and her children, and holds in great consideration the virtues of the right path. Farm work and study are important for her ... (From the Hakka Family Precepts Museum, Hongkeng. May 2015)

A direct timeline connects The Ballad of the Hakka Spouse with the Neize, by way of Ban Zhao's Admonitions for Women (see footnote 23, above) and the women's moral prescription books of the mengxue 蒙学 literature, the primary textbooks for females, such as the Four Books for Women. ${ }^{34}$ The diamesic transformationfrom written text to sung ballad—is a strategy for reaching illiterate subjects such as poor peasants and women.

In traditional society, whereas the education of boys was aimed at preparing for imperial examinations as literati officials or military officers-and, after exams were abolished in 1902, at improving one's social status-the education of girls was limited to the acquisition of basic literacy skills that might allow them to study the mengxue. Through the study of primary books, they acquired competence in a set of traditional practices conveyed in those texts. Through those practices they were not merely regarded as a positive examples, but also reflected the level of civilization of the whole community. The ideal of "virtuous wife and good mother" (xianqi liangmu 贤妻良母), embodied in mengxue instruction manuals, was based on the woman paradigm of the above-mentioned san cong si de (Xu 2011) transmitted in the multi-stratified Confucian school, with its strong emphasis on the predominant position of men in the society (zhongnan qingnü 重男

34 A collection of manuals assembled in 1624. They included, besides Ban Zhao's Admonitions for Women, the Song Sisters' Women's Analecta (Nü Lunyu), Empress Xu's Instructions for Women (Nüxun/Neixun), Lady Liu's Quick Guide for All Rules for Girls (Nüfan Jielu). For a complete translation of the Nü Sishu, see Pang-White 2018. So far, it is the only English edition which includes all the four books in translation. 
轻女). In a line of continuity, and also in modern times, the maintenance of social harmony is based on this, while breaching of the Way of Women leads to disruptive consequences, both within the family and outside, within society (Lieberman 1998; Ebrey 2002; Barlow 2004; Rosenlee 2006; Hershatter 2007).

This is the reason why, from the Ming dynasty onwards, there was a flourishing of educational texts for women. As reported by Huang Majin $(1995,22)$, in the West Fujian Hakka area the more widely-read books for female instruction were:

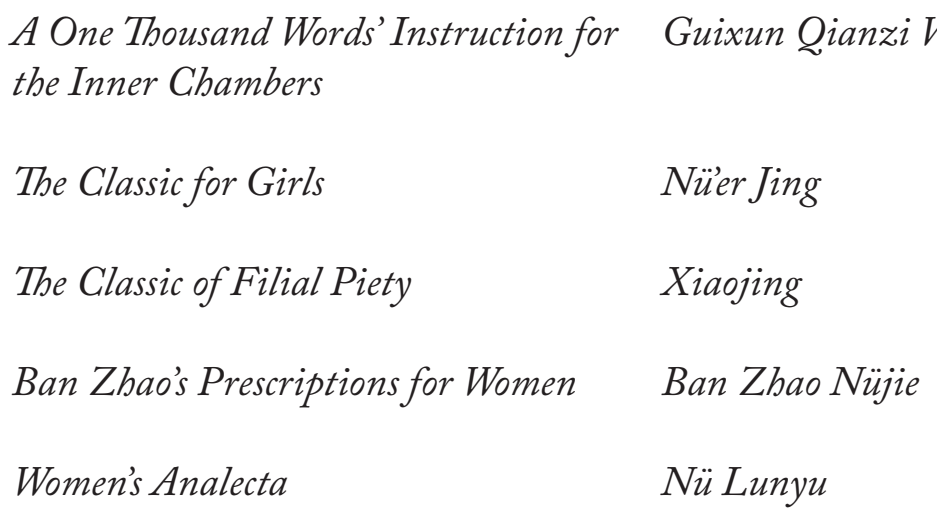

To these texts we shall add also the above-mentioned Zengguang Xianwen 增 广贤文 (Enlarged Writings of Wisdom), and The Ballad of the Hakka Bride (Kejia buniang $c i$ 客家哺娘詞), which was meant to reinforce the womanhood moral prescription.

As mentioned above, at the dawn of the Republican era there was a shift in Hakka women historiography, as a reflection of the intellectual transformations and modernizations that took place on a national scale. In the Minxi region, in continuity with the family school tradition (sishu) noted above, pre-eminent young Hakka men who had studied or worked abroad founded between 1890 and 1910 the first modern schools in Western Fujian, prompted by modernist reformers like Liang Qichao and Kang Youwei. In the Yongding District townships and villages, such as Hongkeng, Gaotou, Xiayang, and in the Liancheng District, the first modern schools provided an education on subjects such as mathematics and science, together with the old classical texts. Girls were admitted to these schools as well, but, other than a few rare exceptions, just for a maximum of three years. A young woman from Gaotou, Jiang Yue'e 江月娥 (1902-1988), whose biography was published in 2007 by her son, Lin Shangxiang, was admitted in 1908 in the local school in Beishan, where the students studied the following (Lin 2007, 35): 
Sanzi jing 三字经, Qianzi wen 千字文, Youxue Jinglin 幼学琼林, Qian jia shi 千 家寺, Guwen Guanzhi 古文观止.

Beside these classical mengxue texts, they studied mathematics and science (ibid.). After the first years, whereas Jiang Yue'e's two brothers were sent to the city to further their education, at 16 she was betrothed and married. She is recorded as an exceptional lady in the area, as she was educated enough to be able to help her husband once they emigrated to South-East Asia and ran imported good shops. Her husband, Lin Fuzhang 林福章, the grandson of a distinguished family from the neighbouring village of Hongkeng, was educated in the local Rixin School (Rixin Xuexiao 日新学校), another modern institution, ${ }^{35}$ one funded by his father, who was a tobacco dealer and had studied in Japan.

There were also schools run by missionaries in Fujian, but not many in the remote hills of Minxi until the years immediately preceding the foundation of the PRC (Xie 2005a, 205-13). The main function of these institutions was that of rescuing orphaned and abandoned girls xxxxxxxx, many of whom, instructed in the Christian faith, became nuns, or emigrated.

In those years the first school for women was established. According to Li (1996, 72), this can be credited to a Guangdong woman from Jiaying, Ye Bihua 叶璧华 (1841-1915). In 1906 she funded the Yide Women's School, in Meixian, with the stated intent of raising the social position of women. Between the year in which this school founded and the first years of the Republic, six other schools for girls were founded in Meixian (former Jiaying), and many Hakka students were hosted there.

Women's liberation and education were the focus of the first documents of the "Political Resolution of the First General Assembly of the Delegates of the Minxi Chinese Communist Party" ${ }^{36}$ of July 1929 (in China Central Archive 1989, 5) and the "Resolution on Women's Movement in Minxi", ${ }^{37}$ February 1930 (Research Center 1986, 90-95).

In this period some women not only acquired education, but also took up an active part in educating other women. Two distinguished cases are those of Fan Lechun (1903-1941) and Zhang Jinghui (1915-1930), both born to poor Yongding farmers, who joined the Chinese Communist Party (CCP) in 1929 and are recorded as women who took their destinies in their hands through education.

35 The Hongkeng Rixin 日新 elementary school was built by the Lin family in 1907 (Xu 2015, 339).

36 Zhongyang Minxi diyi ci daibiao dahui zhi zhengzhi jueyi 中共闽西第一次代表大会之政治决议案.

37 Available at: https://www.marxists.org/chinese/reference-books/ccp-1921-1949/05/053.htm. (Accessed August, 2020.) 
In the next example it is interesting to note the coincidence of two factors in relation to a returnee from abroad (fanke 番客)—education and revolution. Cheng Kangrong's (1915-1940) family was from Qiling, in Yongding, but she had been born in a huaqiao family in Burma. Her father, Cheng Ximei, had taken part in Sun Yatsen's Tongmenghui, and she returned to China with him and her 18-year old sister when she was fifteen. She studied in Jimei high school and enrolled in Xiamen University. ${ }^{38}$ When the Japanese invaded China, she quit her studies and joined the resistance. Given the dangers of the times, her father wanted her to leave the country. But she refused, wanting to follow her Communist comrades. Though disowned by her father and sister, Cheng Kangrong stayed on. With two other young students, Xiao Zheng and Xiao Zhou, she volunteered to teach in village schools, and they began their work in Qiling, acting as CCP underground operatives (Qiling was a Guomindang (GMD) stronghold). In class they used revolutionary and anti-Japanese materials, preparing them personally, and introduced ballads and operas with new contents. In the villages of Shuangshan and Huhe they took part in the foundation of night schools for women. Xiao Zheng was then sent to serve the CCP in Xiamen, while Cheng remained, was captured by the GMD and tortured to death.

Jiang Yue'e, introduced above, was also a fanke, as she returned to her village in 1942, hoping to help her husband recover from tuberculosis. In 1949 she was very active in teaching in night school for farmers, first in Hongkeng and then in other villages, with the help of her daughter, Lin Yunying, who was 29 at the time.

Even if these individuals entered official history as revolutionary women and embodied the new spirit of revolutionary times, the continuity of education of rural Hakka with the traditional moral instruction was not interrupted. Even in the 21st century, the contiguity among historical narrative, folk kejia buniang narrative, and mengxue educational texts stands out to a high degree.

\section{Conclusion}

We identified here the most meaningful paradigms that characterize the socio-cultural construct of the Hakka woman and build her relationship with history: she embodies the sense of rurality; she is in charge of maintaining the knowledge of practices, beliefs, and attitudes that identify the community group; she is responsible for producing male descendants. She is thus entrusted with keeping

38 For this reason she is listed among the revolutionary heroes in Xiamen University Museum. She is the only woman on this list. 
the thread of history intact, through the perpetuation of the lineage, in the fulfilment of the main physical task - that of procreation and the maintenance and education of children - as well as the moral one, i.e. the transmission of cultural knowledge and values through example and ritual practices (yi shen zuo ze 以身作 则). She represents continuity, and also transformation.

By way of conclusion, we might draw four historiographic narratives of the Hakka woman:

1. That of the strong woman (jianfu) committed to work and hardship. This is the most frequent narrative. As we saw in this paper, the sociological feature of Hakka rural communities in which men emigrate and women stay home required endorsing the value of a strong woman capable of taking care not only of the house (the inner space nei traditionally dedicated to the feminine), but also of the outside, the work in the field (etymologically the origin of the character for man nan 男).

2. That of the virtuous woman (xianqi liangmu), also required by the absence of most men from the village. The importance of family values in the Lixue School strongly emphasizes harmony (hexie 和谐) among family members and relies on the capability of the young woman (女) to adapt in the new family as a married woman ( $f u$ 妇), become a mother and then a grandmother. The imperative of marriage and procreation is reinforced by the fact that women's names and stories are inserted into the genealogy books only once they achieved the main moral objective of granting a male descendant to the lineage. These two historiographic models were originally reinforced by the reports of missionaries who, as we have seen, attributed a higher moral value to the Hakka women than to non-Hakka women in an urban environment, and, in rural environments, admired their strength and endurance.

3. That of the revolutionary woman (geming nüxin) born in the Marxist historiographic tradition. As a response to the extreme poverty and subjugation to a patriarchal society, the attention that the Minxi Soviet government (1927-1931) gave to the woman liberation's issue generated many practices which involved female participation in the new, idealized society, such as political agency, literacy, and social liberation. Thus, many women are depicted in Hakka history as revolutionary heroes, from their participation to the Taiping movement, to the First Gannan-Minxi Soviet, and the Long March, on to joining the CCP and grassroots organizations.

This narrative, together with the first two, is quite present in local authors' literary renditions, such as in He Ying's The Tenderness Years published in 2009 and 
serialized on television in 2014 in 30 episodes (The Woman in the Tulou), as well as in biographies on local mothers, written by devoted sons or grandsons with a strong intent to fill the gaps in official historiography—such as the biography of Jiang Yue'e, celebrated in the book written in 2007 by her son, Lin Shangxiang: The Mother in the Tulou. Finally, we may recall here Zhu Xiuhai's 2016, Hakka People, and the 2004 TV series Women Inside the Fortress, where the women's narratives adhere very much to these three models.

4. The model of the global Hakka woman that emerged after the 1990s, when women's emigration began to be highly encouraged by the government. In her migration experience, the Hakka woman knows how to contribute actively to the success of her family history. This is tied to the importance of philanthropy (as in the case of $\mathrm{Hu} \mathrm{Xian} / \mathrm{Sally} \mathrm{Aw}$ ), is praised at the local government level, and celebrated in commemorative steles, family temples and in jiapus and zupus. "Inspirational" women belong to this category, like China's first female conductor, Zheng Xiaoying (1929-), who has become the symbol of Hakka women on account of her personal fame as chief conductor of the China National Opera House.

This configuration of historiographical models for the Hakka woman, which coexist at the same time and emerge in turn according to the discourse and moment within which they are delineated, brings into play Tang Junyi's dichotomy between "moral self" and "real self". ${ }^{39}$ As morality represents the foundation of the self, woman, as an historical subject, is integrated within history and morality at the same time.

\section{References}

An, Guoqiang 安国强. 2015. Kejia da qianxi 客家大迁徙 (Great Hakka Migrations). Beijing: Beijing Normal University Publishing House.

Ardizzoni, Sabrina. 2020. "Women on the Threshold in the First Chapter of Liu Xiang's Lienü Zhuan: The Gendered Concepts of Nei 内/Wai 外 and the Way of Women (Fu Dao 婦道).” Asian Studies 8 (3): 281-302. DOI: 10.4312/ as.2020.8.3.281-302.

Barlow, Tani. 2004. The Question of Women in Chinese Feminism. Durham NC: Duke University Press.

Blum, Susan D., and Lionel M. Jensen, eds. 2002. China Off-Center. Mapping the Margins of the Middle Kingdom. Honolulu: University of Hawai'I Press.

39 "The real self refers to the self as an object of reality, fixed or captured within time and space. It is limited and determined by things and events pertaining to a certain time and space. It is a phenomenal self." (Tang Junyi in Rošker 2011,94) 
Brandtstadter, Susan, and Goncalo D. Santos. 2009. Chinese Kinship: Contemporary Anthropological Perspectives. Routledge Contemporary China Series. London: Routledge.

Bruckermann, Charlotte, and Stephan Feuchtwang. 2016. The Anthropology of China: China as an Ethnographic and Theoretical Critique. London: Imperial College Press.

Cai, Dengqiu 蔡登秋. 2004. "Lun Kejia wenhua goucheng de duoyuanxing 论客 家文化构成的多元性 (On the Multiplicity of Hakka Culture Construct).” Journal of Sanming College 21 (3): 73-77.

Cao, Shuji 曹树基. 2018. “Qingdai qian Zhejiang shanqu de Kejia yimin 清代 前期浙江山区的客家移民 (Pre-Qing Hakka Migration in the Zhejiang Mountains).” In Shijie Kejia Wenku 世界客家文库 (Collected Documents on Hakkas in the World). Accessed July 13, 2020. http://www.hakkaonline.com/ thread-68199-1-1.html.

Ceng, Huidong 曾辉东, Fu Delu 傅德露, and Gao Xiaobin 高晓斌, eds. 2011. Minxi Kejia dadian 闽西客家大典 (Minxi Hakka Dictionary). Fuzhou: Haifeng Publishing House.

Chen, Ju 陈驹. 1992. Chuantong nüzi meng du xinbian 传统女子梦读新编 (New Edition of Traditional Readings for Girls). Guangxi: Guanxi Jiaoyu Chubanshe.

Chen, Xianzhang, ed. 2018. Kejia zudi yu quanqiu Kejia yanjiu taolunhui-Lunwenji 客家祖地与全球客家研究讨论会一论文集 (Acts of the Symposium for Ancestral Hakkaland and Global Hakka Studies). Longyan: Research Center for Mintai Hakka Studies.

Chen, Zhiping 陈支平. 1996. Fujian zupu 福建族谱 (Fujian Genealogy Books). Fuzhou: Fujian People's Publishing House.

China Central Archive. 1989. Zhonggong zhongyang wenjian xuanji 中共中央文件 选集 (Selection of Documents of the Chinese Communist Party). Beijing: Chinese Communist Party Publishing House.

https://www.marxists.org/chinese/reference-books/ccp-1921-1949/05/053. htm.

Cohen, Myron. 1968. “The Hakka or 'Guest People': Dialect as Socio-Cultural Variable in Southeastern China." Ethnobistory 15 (3): 237-92.

—. 1996. "The Hakka or 'Guest People': Dialect as Sociocultural Variable in Southeast China." In Guest People: Hakka Identity in China and Abroad, edited by Nicole Constable, 36-78. Seattle: University of Washington Press.

- 2005. Kinship, Contract, Community, and State: Anthropological Perspectives on China. Stanford: Stanford University Press.

Constable, Nicole. 1996. Guest People: Hakka Identity in China and Abroad. Seattle: University of Washington Press. 
Dennys, N. B., ed. 1867. Notes and Queries on China and Japan, vol. I: January to December 1867. Hong Kong: Charles A. Saint.

—, ed. 1873. The China Review or Notes and Queries the Far East, vol. II: July 1873 to June 1874 . Hong Kong: Kelly and Co.

Ebrey, Patricia. 1991. Chu Hsi's "Family Rituals". A Twelfth Century Chinese Manual for the Performance of Cappings, Weddings, Funerals and Ancestral Rites. Princeton, NJ: Princeton University Press.

Ebrey, Patricia. 2002. Women and the Family in Chinese History. London and New York: Routledge.

Eitel, Ernest John. 1867 "Ethnographical Sketched of the Hakka Chinese." In Notes and Queries on China and Japan, edited by N. B. Dennys, 65-67. Hong Kong: Charles A. Saint.

Eitel, Ernest John. 1873: "An Outline History of the Hakkas." In The China Review or Notes and Queries the Far East, edited by N. B. Dennys, 160-64. Hong Kong: Kelly and Co.

Erbaugh, Mary S. 1992. "The Secret History of the Hakkas: The Chinese Revolution as a Hakka Enterprise." The China Quarterly 132: 937-68.

- 2002. "The Secret History of the Hakkas: The Chinese Revolution as a Hakka Enterprise." In China Off-Center. Mapping the Margins of the Middle Kingdom, edited by Susan D. Blum, and Lionel M. Jensen, 185-213. Honolulu: University of Hawai'I Press.

Fang, Xuejia. 2012. Kejia heliu 客家河流 (The Hakka People Flow). Canton: South China University of Technology Press.

Fang, Xuejia et al. 2012. Kejia funü shibui yu wenhua 客家妇女社会与文化 (Hakka Women Society and Culture). Canton: South China University of Technology Press.

Fang, Xuejia, and Huang Chongcai, eds. 2011. Jiedu Kejia lishi yu wenhua 解读客 家历史与文化 (Interpreting Hakka History and Culture). Beijing: Intellectual Property Publishing House.

Faure, David. 1990. The Structure of Chinese Rural Society: Lineage and Village in the Eastern New Territories. Hong Kong: Oxford University Press.

- 2007. Empires and Ancestors: State and Lineage in South China. Stanford: Stanford University Press.

Fei, Xiaotong. 1988. Plurality and Unity in the Configuration of the Chinese People. Tanner Lecture: Chinese University of Hong Kong.

Feuchtwang, Stephen. 2001. Popular Religion in China: The Imperial Metaphor. London: Curzon

Freedman, Maurice. 1958a [1970]. Lineage Organization in Southeastern China. London: Althone Press. 
- 1958b. Chinese Lineage and Society: Fukien and Kwangtung. London: London School of Economics.

—, ed. 1970. Family and Kinship in Chinese Society. Stanford, CA: Stanford University Press.

Ge, Wenqing 葛文清. 1999. “'Minxi’ he 'Kejia' gainian de jieding yu Song Yuan yilai Kejia qianyi 民系” 和 “客家”概念的界定与宋元以来客家迁移 (The Origin of 'Lineage' and 'Hakka' Determined in Post-Song and Yuan Migrations)." Journal of Longyan University 1: 54-59.

He, Ying 何英. 2009. Fumo suiyue 抚摸岁月 (The Tenderness Years). Beijing: Writers' Publishing House.

Hershatter, Gail. 2007. Women in China's Long Twentieth Century. Berkeley: University of California Press.

$\mathrm{Hu}$, Daxin 胡大新. 2009 [2006]. Yongding Kejia tulou yanjiu 永定客家土楼研 究 (Yongding Hakka Earth Building Research). Beijing: Zhongyang Wenxian Publishing House.

Hu, Hongbao, Wang Jianmin, and Zhang Haiyang. 2014 [2006]. Storia dell'antropologia cinese (History of Chinese Anthropology). Edited and translated by Andrea Pia. Torino: SEID.

$\mathrm{Hu}$, Saibiao 胡塞表. 2019.Jimo de Hu Wenhu 寂寞的胡文虎 (Hu Wenhu, a Lonely Man). Hong Kong: Tianma Dushu LLC.

Huang, Hanmin. 2020. Fujian Tulou. A Treasure of Chinese Traditional Civilian Residence. Singapore: Springer.

Huang, Majin 黄马金. 1995. Kejia funü 客家妇女 (Hakka Women). Beijing: Women's Publishing House.

Legge, James. 1885. The Sacred Books of China. The Texts of Confucianism, part III. The Sacred Books of the East. Vol. XXVII. Oxford: Clarendon Press.

Leo, Deow, and Dai Yifeng. 2000. West Fujian: Land and Migration 1910s-1940s. Xiamen: Xiamen University Press.

Leong, Sow-Theng, and Tim Wright, eds. 1997. Migration and Ethnicity in Chinese History-Hakkas, Pengmins and their Neighbors. Stanford: Stanford University Press.

Li, Yongji 李泳集. 1996. Xingbie yu wenhua: Kejia funü yanjiu de xin shiye 性别 与文化: 客家妇女研究的新视野 (Gender and Culture: New Perspectives in Hakka Women Studies). Canton: Guangdong People's Publishing House.

Lieberman, Sally Taylor. 1998. The Mother and Narrative Politics in Modern China. Charlottesville, London: University Press of Virginia.

Lin, Shangxiang 林尚祥. 2007. Tulou li de muqin 土楼里的母亲 (Mother of the Tulou). Fuzhou: Haixia Wenyi Publishing House. 
Lin, Xiaoying 林萧影. 2006. Fujian minzu minjian chuantong wenhua: lishi, xianzhuang yu sikao 福建民族民间传统文化: 历史, 现状与思考 (The People of Fujian and Traditional Culture: History, Current Situation and Thought). Fuzhou: Fujian People's Publishing House.

Lin, Zhenghui 林正慧. 2015. Taiwan Kejia de xinsu licheng Qingdai zhi zhanhou de zhuisuo 台灣客家的形塑歷程清代至戰後的追索 (Historical Process of the Formation of Taiwanese Hakka: From the Qing Dynasty to the Post-War Period). Taibei: National Taiwan University Press.

Liu, Yonghua. 2013. Confucian Rituals and Chinese Villagers: Ritual Change and Social Transformation in a Southeastern Chinese Community, 1368-1949. Religion in Chinese Societies. Boston: Brill.

Luo, Xianglin 罗香林. 1989 [1933]. Kejia yuanliu kao 客家源流考 (Study on Hakka Origins). Beijing: The Chinese Overseas Publishing House.

1992 [1933]. Kejia yanjiu daolun 客家研究导论 (Introduction to Hakka Studies). Shanghai: Shanghai Wenyi Publishing House.

—. 2018. Kejia yanjiu daolun一wai yi zhong 客家研究导论一外一种: 客家源 流考 (Introduction to Hakka Studies—Added: A Study on Hakka Origins). Canton: Guangdong Peoples' Publishing House.

Luo, Zhiye 罗志野. 2017. “Liji” Ying yi 《礼记》英译 (English Translation of the Liji). Nanjing: Eastern University Publishing House.

Malighetti, Roberto. 2014. Antropologie dalla Cina (Anthropologies from China). Torino: SEID.

Mauss, Marcel. 2002 [1934]. "Les Techniques du corps.” Journal de Psychologie XXXII 3-4: March 15-April 15, 1936. Document produit en version numérique par Jean-Marie Tremblay. http://classiques.uqac.ca/classiques/ mauss_marcel/socio_et_anthropo/6_Techniques_corps/Techniques_corps. html.

Minxi Hakka Friendship Association Minxi Kejia Lianyuhui 闽西客家联谊会. 2013. Minxi Kejia waiqian yanjiu wenji 闽西客家外迁研究文集 (A Collection of Studies on the Migration of Hakka from West Fujian). Longyan: Haixia Wenyi Publishing House.

Pang-White, Ann. 2018. The Confucian Four Books for Women: A New Translation of the Nü Sishu and the Commentary of Wang Xiang. New York: Oxford University Press.

Piton, Ch. 1873. "On the Origin and the History of the Hakkas." In The China Review or Notes and Queries the Far East. Vol. II: July 1873 to June 1874, edited by N. B. Dennys, 222-26. Hong Kong: Kelly and Co.

Research Center for Women Movement History of the All China Women Association. 1986. Zhongguo funü lishi ziliao: 1927-1937 中国妇女历史资料: 1927-1937 (Sources on Chinese Women History 1927-1937). Beijing: China Women Publishing House. 
Rosenlee, Li-Hsiang Lisa. 2006. Confucianism and Women: A Philosophical Interpretation. Albany: State University of New York Press.

Rošker, Jana S. 2016. The Rebirth of the Moral Self. Hong Kong: The Chinese University Press.

— 2017. "Between Tradition and Modernity: Modern Confucianism as a Form of East Asian Social Knowledge." Asian Studies 5 (21) 2: 43-62.

Wang, Robin. 2003. Images of Women in Chinese Thought and Culture: Writings from the Pre-Qin Period through the Song Dynasty. Indiandapolis/Cambridge: Hackett Publishing.

Wu, Fuwen 吴福文. 2011. “Kejia funü de jiaose yu diwei 客家妇女的角色与地 位 (Hakka Women's Role and Position).” Journal of Longyan University 29 (3): 16-21.

Wu, Yongzhang 吴永章. 2012. Duoyuan yiti de Kejia wenhua 多元一体的客家 文化 (Plural Unity of Hakka Culture). Canton: South China University of Technology Press.

Xie, Chongguang 谢重光. 2002. Minxi Kejia 闽西客家 (Fujian’s Hakka). Beijing: Xinhua Shudian.

—. 2003. Mintai Kejia shehui yu wenhua 闽台客家社会与文化 (Hakka Society and Culture in Fujian and Taiwan). Fuzhou: Fuzhou People's Publishing House.

—. 2005a. Kejia wenhua yu funü shenghuo: 12-20 shiji Kejia funü yanjiu 客家文 化与妇女生活: 12-20世纪客家妇女研究 (Hakka Culture and Women's Life: A Research on 12-20th Century Hakka Women). Shanghai: Shanghai Classics Publishing House.

— . 2005b. “Kejia funü renwen xingge ji qi lishi chengyin 客家妇女人文性 格及其历史成因 (Historical Reasons of Hakka Women Characteristics).” Journal of Fuzhou University (Philosophy and Social Sciences Edition) 2 (1): 86-91.

- 2005c. Fujian Kejia 福建客家 (Fujian Hakka People). Guilin: Guangxi Normal University Publishing House.

—. 2005d. "Song Ming Lixue yingxiang xia Kejia funü shenghuo de bianyan 宋明理学影响下客家妇女生活的演变 (The Evolution of Hakka Women’s Lives under the Influence of the Lixue School during the Song and Ming Period)." Journal of Fujian Party School 5: 47-51. DOI:10.15993/j.cnki. cn35-1198/c.2005.05.013.

—. 2009. “Tulou zhi gen yu Tulou wenhua de jingsui 土楼之根与土楼文化 的精髓 (Tulou Roots and the Quintessence of Tulou Culture).” Zhonggong Fujiansheng weidangxiao xuebao (Journal of Fujian Party School) 6: $77-81$. 
- 2011. “Kejia wenhua de Zhongyuan qingjie yu caogen bense 客家文化的 中原情结与草根本色 (The Sense of Belonging to Central China in Hakka Culture and Roots Issue).” In Jiedu Kejia lishi yu wenhua 解读客家历史与 文化 (Interpreting Hakka History and Culture), edited by Fang Xuejia, and Huang Chongcai, 5-19. Beijing: Intellectual Property Publishing House.

- 2012. "Guanyu Kejia yimin yu wenhua rentong ruogan wenti de sikao 关于 客家移民与文化认同若干问题的思考 (On Hakka Migrants and their Cultural Identity)." Journal of Guangxi University for Nationalities 34 (3): 17-25.

Xin, Geng 心根. 1933. “Zhide zhuyi de Guangdong Kejia nüzi 值得注意的广东 客家女子 (Notable Cantonese Hakka Women).”Funü gongming 妇女共鸣 (The Echo of Women) 2 (2): 22-30.

$\mathrm{Xu}$, Weiqun 徐维群. 2016. Kejia wenhua fuhaolun 客家文化符号论 (On the Symbols of Hakka Culture). Xiamen: Xiamen University Press.

$\mathrm{Xu}$, Yingying 徐莹莹. 2011. “Chuyi jiu zhi 《Lienü Zhuan》zhong de Kejia funü xingxiang-Yi Qianlong 《Tingzhoufu zhi》wei yanjiu shijiao 刍议旧志 《 列女传》中的客家妇女形象一以乾隆 《汀州府志》为研究视角 $(\mathrm{On}$ the Image of Hakka Women in the Biographies for Chaste Women: A Study Based on the Tingzhou Municipal Records of Qianlong)." Journal of Gannan Normal University 32 (1): 21-24.

$\mathrm{Xu}$, Yuanlong 徐元龙, ed. 2015. Yongdingxian zhi-Minguo 永定县志一民国 (Yongding Gazette-Republican Era). Xiamen: Xiamen University Publishing House.

Yuan, Jiahua 袁家骅. 1983 [1960]. Hanyu fangyan gaiyao 汉语方言概要 (Outline of Chinese Dialects). Beijing: Language Reform Publishing House.

Zeng, Yueying 曾曰英. 1748. Tingzhoufu zhi 汀州府志 (Tingzhou Gazette). Accessed August,2020.https://ctext.org/wiki.pl?if=gb\&res=277120\&remap=gb.

Zhang, Dingxiong 张定雄, ed. 1994. Yongdingxian zbi 永定县志 (Yongding Gazette). Xiamen: Xiamen University Press.

Zheng, Xincai 郑新彩. 2009. Yongding Kejia Tulou zhi 永定客家土楼志 (History of Yongding Hakka tulous). Yongding: Local Gazette Publishing House.

Zhou, Jinshui 周金水. 2018. “Manyue Lisu yu jinji 满月礼俗与禁忌 (Customs and Taboo for Manyue)." In Kejia zudi yu quanqiu Kejia yanjiu taolunbuiLunwenji 客家祖地与全球客家研究讨论会一论文集 (Acts of the Symposium for Ancestral Hakkaland and Global Hakka Studies), edited by Chen Xianzhang, 537-44. Longyan: Research Center for Mintai Hakka Studies.

Zhu, Xiuhai 朱秀海. 2016. Kejiaren 客家人 (Hakka People). Nanchang: Baihua zhou wenyi chubanshe. 